\section{One-Year Water Sorption and Solubility of "All-in-One" Adhesives}

Ricardo Walter ${ }^{1}$, Andrew E. Feiring ${ }^{2}$, Lee W. Boushell ${ }^{3}$, Krista Braswell ${ }^{3}$, Whitley Bartholomew ${ }^{3}$, Yunro Chung $^{4}$, Ceib Phillips ${ }^{5}$, Patricia N. R. Pereira ${ }^{6}$, Edward J. Swift, Jr. ${ }^{3}$

\begin{abstract}
The aim of this study was to evaluate the water sorption and solubility of different adhesives. Adper Easy Bond, Adper Single Bond Plus, Bond Force, Clearfil SE Bond (bonding resin only), and Xeno IV were the materials evaluated. Ten disks of each adhesive were made in Teflon molds and evaporation of any volatile components was allowed. The disks were weighed daily in an analytical balance until a constant mass was obtained $\left(m_{1}\right)$. Disks were then immersed in water for 12 months when their wet weight was recorded $\left(m_{2}\right)$. The disks were again weighed daily until a constant mass was obtained and the final weight recorded $\left(m_{3}\right)$. Water sorption and solubility (percentages) were calculated using the recorded mass values. Kruskal-Wallis tests were used to compare the average water sorption and solubility among the different adhesives. Mann-Whitney tests with a Bonferroni correction were used to determine the pairwise differences between adhesives in water sorption and solubility. The level of significance was set at 0.05 . Water sorption and solubility were significantly different among the groups $(p<0.05)$. Pairwise comparisons showed no significant differences $(p>0.05)$ between Adper Single Bond Plus and Bond Force, or between Clearfil SE Bond and Xeno IV in either water sorption or solubility. Xeno IV did not differ from Adper Easy Bond in water sorption ( $p>0.05)$. Water sorption and solubility of all-in-one adhesives increased with time, and the rates of increase were composition-dependent. The results suggest that monomers other than HEMA contribute to water sorption and solubility of adhesive systems from different categories.
\end{abstract}

\author{
'Department of Preventive and \\ Restorative Sciences, University \\ of Pennsylvania Robert Schattner \\ Center School of Dental Medicine, \\ Philadelphia, PA, USA \\ ${ }^{2}$ Department of Chemistry, University \\ of Pennsylvania School of Arts \&t \\ Sciences, Philadelphia, PA, USA \\ ${ }^{3}$ Department of Operative Dentistry, \\ University of North Carolina School \\ of Dentistry, Chapel Hill, NC, USA \\ ${ }^{4}$ Department of Biostatistics, \\ University of North Carolina \\ Gillings School of Global Public \\ Health, Chapel Hill, NC, USA \\ ${ }^{5}$ Department of Orthodontics, \\ University of North Carolina School \\ of Dentistry, Chapel Hill, NC, USA \\ ${ }^{6}$ Department of Dentistry, University \\ of Brasilia Health Sciences \\ School, Brasilia, DF, Brazil
}

Correspondence: Ricardo Walter, 240 South $40^{\text {th }}$ Street, Philadelphia, PA 19104, USA. Tel:+1-215-898-9164. e-mail: walterr@dental.upenn.edu

Key Words: water sorption, solubility, dental adhesives.

\section{Introduction}

Since their introduction in the late 1990's, manufacturers have attempted to develop all-in-one adhesives that effectively bond to the tooth structures and do not suffer from long-term hydrolytic degradation. While associations between degradation of such materials and cytotoxicity (1) and reduction in bond strengths (2) are questionable, hydrolysis of such materials is believed to negatively influence their clinical performance.

To properly infiltrate hard tooth tissues, specifically dentin, all-in-one adhesives combine etch, prime and bond functions in a single solution. The combined product is very hydrophilic given the water solvent and 2-hydroxyethyl methacrylate (HEMA) present in most. The function of water is to ionize acidic monomers while that of HEMA is to enhance wetting of dentin and keep hydrophilic and hydrophobic monomers stable in solution (3). Higher water sorption for all-in-one adhesives compared with threestep etch-and-rinse and two-step self-etch adhesives (4), a positive association between HEMA content and adhesive degradation $(5,6)$, and an association between hydrophilicity of adhesives and water sorption and solubility $(7,8)$ have been reported.

Hydrolytic degradation of a dental adhesive begins with water entering the polymer. Chemical degradation is likely to begin by hydrolysis of the ester bonds, which release small molecule alcohols and begin degrading the crosslinked structures created during resin polymerization (9). Dissolution of water-soluble small molecules creates voids. Acids, created by ester hydrolysis, will decrease $\mathrm{pH}$, enhancing the acid-catalyzed ester hydrolysis process (10). Both HEMA and BIS-GMA have been shown to elute within $24 \mathrm{~h}$ from methacrylate-based self-etch adhesives, which is likely due to simple extraction of unpolymerized monomers (11). However, solubility of adhesives has been shown to continually increase over 180 days (12). Systems based on hydrophobic monomers (13) and non-solvated adhesives appear to absorb less water (7).

Resin-based restorative materials, including adhesives, do not polymerize completely; however, no direct association between degree of conversion and water sorption $(14,15)$ and elution of unreacted monomers seems to exist (11). On the other hand, an inverse association between water sorption and ultimate tensile strength has been reported $(6,16,17)$. Water sorption also may affect the modulus of elasticity of adhesives, but this is a controversial subject (16-18).

The purpose of this study was to evaluate the water sorption and solubility of three all-in-one adhesives compared with the bonding resin of a two-step self-etch 
adhesive and a HEMA-containing two-step etch-and-rinse adhesive. Water sorption and solubility (percentages) were assessed after 1 year of water storage. The hypothesis tested was that water sorption and solubility of all-in-one adhesives increase over time and do so at rates greater than those of the control materials.

\section{Material and Methods}

Five adhesives from different categories were tested. The materials along with manufacturers and compositions are listed in Table 1. Ten disks of each adhesive were made. Materials were dispensed in Teflon molds with dimensions of $6 \mathrm{~mm}$ in diameter and $2 \mathrm{~mm}$ in depth. Disk spaces were initially filled to half of their depth and full evaporation of the solvents was attempted with an air-syringe. The remaining halves of the molds were then filled, solvents were once again evaporated, and any air bubbles were removed prior to light curing with an Ultra-Lume 5 (Ultradent, South Jordan, UT, USA) LED curing device for $40 \mathrm{~s}$. Specimens were removed from the molds and

Table 1. Composition of adhesives

\begin{tabular}{|c|c|c|}
\hline Adhesive/category & Manufacturer & Composition ( $\%$ by weight) \\
\hline $\begin{array}{l}\text { Adper Easy Bond / } \\
\text { One-step self-etch }\end{array}$ & $\begin{array}{l}\text { 3M ESPE, St. } \\
\text { Paul, MN, USA }\end{array}$ & $\begin{array}{c}\text { 15-25\% BIS-GMA } \\
\text { 15-25\% HEMA } \\
\text { 10-15\% ethanol } \\
\text { 10-15\% water } \\
\text { 5-15\% phosphoric acid-6-methacryloxy-hexylesters } \\
\text { 8-12\% silane treated silica } \\
5-10 \% \text { 1,6-hexanediol dimethacrylate } \\
\text { 1-5\% copolymer of acrylic and itaconic acids } \\
1-5 \% \text { DMAEMA } \\
\text { 1-3\% camphorquinone } \\
1-3 \% \text { 2,4,6-trimethylbenzoyldiphenylphosphine oxide }\end{array}$ \\
\hline $\begin{array}{l}\text { Adper Single Bond Plus / } \\
\text { Two-step etch-and-rinse }\end{array}$ & $\begin{array}{l}\text { 3M ESPE, St. } \\
\text { Paul, MN, USA }\end{array}$ & $\begin{array}{c}\text { 25-35\% ethyl alcohol } \\
\text { 10-20\% BlS-GMA } \\
\text { 10-20\% silane treated silica } \\
5-15 \% \text { HEMA } \\
5-10 \% \text { copolymer of acrylic and itaconic acids } \\
5-10 \% \text { glycerol 1,3-dimethacrylate } \\
<5 \% \text { water } \\
1-5 \% \text { UDMA }\end{array}$ \\
\hline $\begin{array}{l}\text { Bond Force / } \\
\text { One-step self-etch }\end{array}$ & $\begin{array}{l}\text { Tokuyama Dental } \\
\text { Corporation, } \\
\text { Tokyo, Japan }\end{array}$ & $\begin{array}{c}\text { 30-60\% propan-2-ol } \\
10-30 \% \text { BIS-GMA } \\
10-30 \% \text { HEMA } \\
\text { 10-30\% methacryloxyalkyl acid phosphate } \\
5-10 \% \text { TEGDMA } \\
5-10 \% \text { water } \\
<1 \% \text { BHT } \\
<1 \% \text { camphorquinone } \\
<1 \% \text { diphenyl( } 2,4,6 \text {-trimethylbenzoyl)phosphine oxide } \\
<1 \% \text { MEQUINOL }\end{array}$ \\
\hline $\begin{array}{l}\text { Clearfil SE Bond - Bonding resin } \\
\text { Two-step self-etch }\end{array}$ & $\begin{array}{l}\text { Kuraray Medical, } \\
\text { Inc., Tokyo, Japan }\end{array}$ & $\begin{array}{c}25-45 \% \text { BIS-GMA } \\
20-40 \% \text { HEMA } \\
\text { Undisclosed percentages: MDP, hydrophobic aliphatic methacrylate, } \\
\text { colloidal silica, dl-camphorquinone, initiators, accelerators }\end{array}$ \\
\hline $\begin{array}{l}\text { Xeno IV / } \\
\text { One-step self-etch }\end{array}$ & $\begin{array}{l}\text { Dentsply Caulk, } \\
\text { Milford, DE, USA }\end{array}$ & $\begin{aligned} & <50 \% \text { acetone } \\
& <15 \% \text { UDMA } \\
& <10 \% \text { HEMA } \\
<10 \% \text { TMPTMA } & <10 \% \text { 3-(acryloyloxy)-2-hydroxypropyl methacrylate }\end{aligned}$ \\
\hline
\end{tabular}

BIS-GMA: bisphenol A diglycidyl ether dimethacrylate; BHT: dibutyl hydroxy toluene; DMAEMA: 2-(dimethylamino)ethyl methacrylate; HEMA: 2-hydroxyethyl methacrylate; MDP: 10-methacryloyloxydecyl dihydrogen phosphate; MEQUINOL: 4-methoxylphenol; TEGDMA: triethylene glycol dimethacrylate; TMPTMA: trimethylolpropane trimethacrylate; UDMA: urethane dimethacrylate.

Source: Manufacturers' MSDS and direct communication with manufacturers. 
their thickness was measured using an electronic caliper (Mitutoyo Corporation, Tokyo, Japan), prior to storage at $37^{\circ} \mathrm{C}$ to allow for complete evaporation of any volatile components.

Disks were weighed daily using an analytical balance (AB54-S; Mettler-Toledo Inc., Columbus, OH, USA) until a constant mass $\left(m_{1}\right)$ was obtained. A mass that did not change more than $0.02 \mathrm{mg}$ during a 24-h cycle was considered constant. Once a constant mass was achieved and recorded, specimens were immersed in distilled water (6 $\mathrm{mL}$ vials) for 1 year. Their wet weigh - specimens were lightly dried with a KimWipe (Kimberly-Clark Corporation, Irving, TX, USA) - was recorded at the end of 12 months $\left(m_{2}\right)$ when the same weighing procedure detailed for $m_{1}$ was performed and the final dry weigh recorded as $m_{3}$.

Water sorption and solubility (percentages) were calculated using the following equations:

$$
\begin{aligned}
& \text { Water sorption }=\frac{\underline{m}_{2}-m_{3}}{m_{2}} \times 100 \\
& \text { Water solubility }=\frac{\underline{m}_{1}-m_{3}}{m_{1}} \times 100
\end{aligned}
$$

Kruskal-Wallis test was used to assess the differences in set at 0.05 and all analyses were performed using R 2.14.1 free software for statistical computing (www.R-project.org).

\section{Results}

Figure 1 shows the data for water sorption and solubility for each group. There were statistically significant average differences in both water sorption $(p<0.01)$ and solubility $(p<0.01)$ among the adhesives. Adper Single Bond Plus had the highest average water sorption and solubility although the variability was considerably greater for that adhesive than in the other adhesives excepting Xeno IV (Fig. 1). The pairwise comparisons between adhesives are presented in Table 2. No significant differences ( $p>0.05$ ) were found between Adper Single Bond Plus and Bond Force, or between Clearfil SE Bond and Xeno IV ( $p>0.05)$ in both water sorption and solubility. Xeno IV did not differ from Adper Easy Bond in water sorption ( $p>0.05$ ). All other pairwise comparisons were significantly different $(p<0.05)$.

\section{Discussion}

The hypothesis that water sorption and solubility of all-in-one adhesives increase over time and do so at rates greater than those of the control materials was partially rejected. While water sorption and solubility of all-inone adhesives did increase over time, the rates were no greater than those of the control materials. In fact, one of the control materials, Adper Single Bond Plus, had the highest water sorption and solubility, being similar only to those of Bond Force.

According to the Materials Safety Data Sheets (MSDS) of the materials, all of the adhesives tested contain the highly water-soluble HEMA monomer, substantial quantities of one to three crosslinking monomers, and usually smaller quantities of phosphoric acid monomer(s) to improve adhesion. The manufacturers provide only composition ranges so it is difficult to draw specific structureproperty associations based on composition. However, all
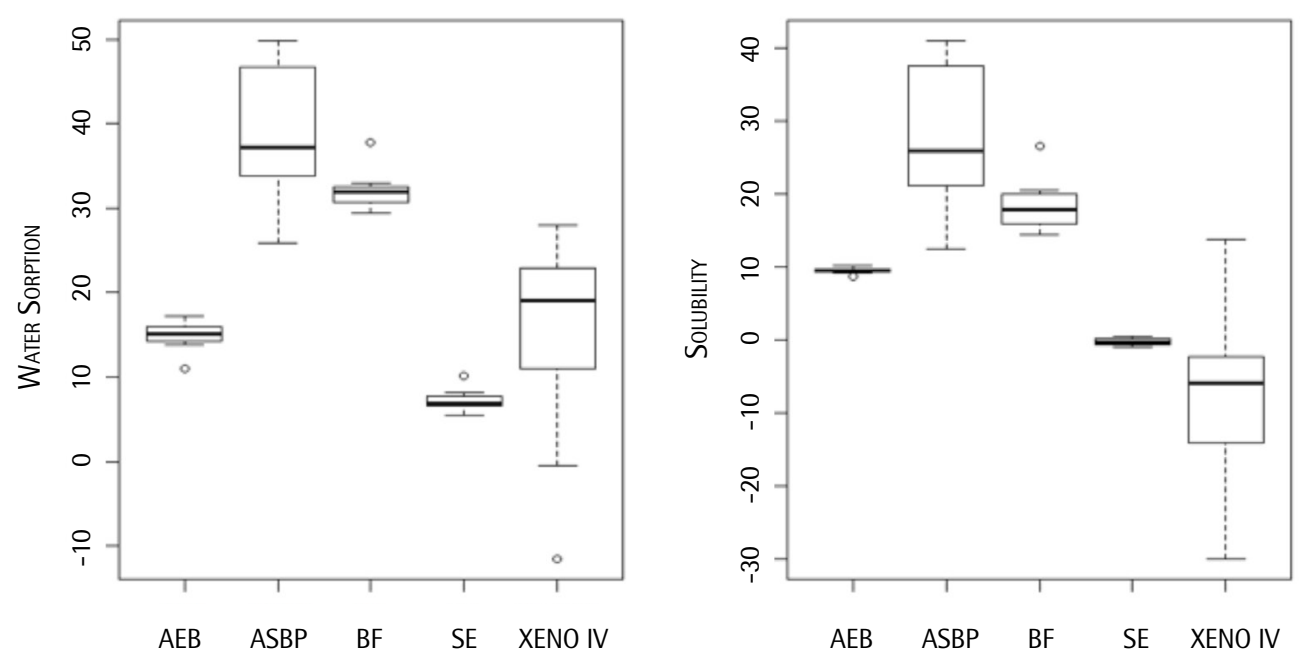

Figure 1. Box plots showing percentage water sorption and solubility by adhesive. AEB: Adper Easy Bond. ASBP: Adper Single Bond Plus. BF: Bond Force. SE: Clearfil SE Bond. 
monomer-based components contain ester groups, which can undergo hydrolysis in the presence of water (9). As mentioned, hydrolysis leads to release of small molecule alcohols, some of which have substantial water solubility especially ethylene glycol from HEMA and glycerol from dimethacrylates (19). Ester hydrolysis will also begin to remove the network crosslinks, which could ultimately result in destruction of the network and dissolution of the polymer backbone (20).

Although HEMA segments are the most hydrophilic, there appears to be little association between water absorbance and HEMA content. For example, the bonding resin of Clearfil SE Bond has the lowest water sorption but among the highest HEMA content. Conversely, Adper Single Bond Plus and Bond Force have high water sorption and low to moderate HEMA levels. Concerns over HEMA solubility have resulted in the development of adhesives that do not contain HEMA. HEMA-free adhesives have been shown to absorb less water than adhesives that contain HEMA and have shown promising clinical performance (21).

There seems to be a somewhat crude association between water sorption and solubility. The adhesives with the highest water sorption show the highest solubility (Adper Single Bond Plus and Bond Force) while the lowest water sorption presented the lowest solubility (Clearfil SE Bond - not different from Xeno IV). The question is cause and effect. If weight loss is due to the hydrolysis of ester bonds leading to formation of water-soluble fragments, higher water content leads to enhance hydrolysis rates, but enhanced hydrolysis should lead to greater void formation, which would enhance water sorption. Hydrolysis also leads to formation of acid groups on the polymer backbone. These acid groups are more hydrophilic than their ester precursors and may catalyze ester hydrolysis.

Some compositions contain "silane-treated silica," but the presence or absence of this filler seems to have little association with water sorption or solubility (22). Although silica tends to have a hydrophilic surface, silane treatment renders the surface less hydrophilic and more compatible with the organic monomers (23).

It is currently unknown whether there is a significant level of unreacted monomer present in the initial test samples and if this fraction varies from adhesive to adhesive. Unreacted monomer might lead to a rapid initial weight loss (and generation of voids) followed by a slower weight loss due to chemical reaction (ester hydrolysis). It may also be useful to independently determine the degree of reaction of the monomers in each adhesive during the initial curing process.

A limitation of the current investigation is the thickness of the test specimens. Specimens were $2 \mathrm{~mm}$ in thickness, which does not mimic the clinical situation. Reasons for utilizing such specimens include ease of manipulation and recording measurements throughout the experiments. Nevertheless, 2-mm-thick specimens are within the range of $0.5 \mathrm{~mm}$ to $3 \mathrm{~mm}$ published in the literature for similar experiments $(2,18)$.

The clinical significance of the findings of this study is

Table 2. Pairwise comparisons between two groups by Mann-Whitney tests

\begin{tabular}{|c|c|c|c|c|c|}
\hline \multirow[b]{2}{*}{ Group 1} & \multirow[b]{2}{*}{ Group 2} & \multicolumn{2}{|c|}{ Water sorption } & \multicolumn{2}{|c|}{ Solubility } \\
\hline & & $\begin{array}{l}\text { Median Diff } \\
(\mathrm{Gr} 1-\mathrm{Gr} 2)\end{array}$ & $p^{1)}$ & $\begin{array}{l}\text { Median Diff } \\
\text { (Gr1 - Gr2) }\end{array}$ & $p^{1)}$ \\
\hline \multirow{4}{*}{ Adper Easy Bond } & Adper Single Bond Plus & -22.17 & 0.0001 & -16.48 & 0.0001 \\
\hline & Bond Force & -16.96 & 0.0001 & -8.47 & 0.0001 \\
\hline & Clearfil SE Bond & 8.20 & 0.0001 & 9.71 & 0.0018 \\
\hline & Xeno IV & -4.05 & 1.0000 & 15.43 & 0.0299 \\
\hline \multirow{3}{*}{$\begin{array}{l}\text { Adper Single } \\
\text { Bond Plus }\end{array}$} & Bond Force & 5.22 & 0.1854 & 8.01 & 0.0520 \\
\hline & Clearfil SE Bond & 30.37 & 0.0001 & 26.19 & 0.0018 \\
\hline & Xeno IV & 18.12 & 0.0004 & 31.91 & 0.0004 \\
\hline \multirow{2}{*}{ Bond Force } & Clearfil SE Bond & 25.16 & 0.0001 & 18.18 & 0.0018 \\
\hline & Xeno IV & 12.90 & 0.0002 & 23.90 & 0.0002 \\
\hline Clearfil SE Bond & Xeno IV & -12.25 & 0.4347 & 5.72 & 0.4536 \\
\hline
\end{tabular}

1) $p$-value was adjusted by the Bonferroni method. 
unclear. Other studies have reported stable bond strengths for Bond Force, which was one of the two adhesives with the greatest water sorption and solubility in this study $(2,24)$. Moreover, a clinical study from Perdigao et al. (25) reported no difference in retention rates between Adper Easy Bond and Adper Single Bond Plus, which had significantly different water sorption and solubility in the present study.

In the present study, water sorption and solubility of all-in-one adhesives increased with time, and the rates of increase were composition-dependent. The results suggest that different monomers contribute to water sorption and solubility of adhesive systems.

\section{Resumo}

0 objetivo deste estudo foi avaliar a absorção de água e a solubilidade de diferentes sistemas adesivos: Adper Easy Bond, Adper Single Bond Plus, Bond Force, Clearfil SE Bond (apenas a resina adesiva) e Xeno IV. Foram fabricados 10 discos de cada material em moldes de Teflon e foi permitida a evaporação de todos os componentes voláteis. Os discos foram pesados diariamente em balança analítica até atingir massa seca constante $\left(m_{1}\right)$. Após esta mensuração, os discos foram imersos em água por 12 meses e seu peso úmido foi anotado $\left(m_{2}\right)$. Os discos foram novamente pesados diariamente até obter-se massa constante $\left(m_{3}\right)$. As percentagens de absorção de água e solubilidade foram calculadas utilizando os valores de massa registrados. A comparação das médias de absorção de água e solubilidade entre os diversos adesivos foi feita com o teste KruskalWallis. As diferenças de absorção de água e solubilidade entre os pares de adesivos foram determinadas pelo testes Mann-Whitney com correção de Bonferroni. 0 nivel de significância adotado foi de 0,05. Absorção de água e solubilidade apresentaram diferenças estatisticamente significantes entre os grupos $(p<0,05)$. As comparações pareadas dos adesivos não mostraram diferenças significantes $(p>0,05)$ entre Adper Single Bond Plus e Bond Force nem entre Clearfil SE Bond e Xeno IV para absorção de água e solubilidade. Xeno IV apresentou diferença significante do Adper Easy Bond quanto à absorção de água $(p>0,05)$. A absorção de água e solubilidade dos adesivos "all-in-one" aumentaram com o tempo e as taxas de aumento mostraram-se dependentes da composição do material. Os resultados sugerem que outros monômeros além do HEMA contribuem para a absorção de água e solubilidade dos diversos sistemas de adesivos.

\section{References}

1. Kaga M, Noda M, Ferracane JL, Nakamura W, Oguchi H, Sano H. The in vitro cytotoxicity of eluates from dentin bonding resins and their effect on tyrosine phosphorylation of L929 cells. Dent Mater 2001;17:333339.

2. Itoh S, Nakajima M, Hosaka K, Okuma M, Takahashi M, Shinoda $Y$, et al.. Dentin bond durability and water sorption/solubility of one-step self-etch adhesives. Dent Mater J 2010;29:623-630.

3. Van Landuyt KL, Snauwaert J, De Munck J, Peumans M, Yoshida $Y$, Poitevin A, et al.. Systematic review of the chemical composition of contemporary dental adhesives. Biomaterials 2007;28:3757-3785.

4. Dhanpal P, Yiu CK, King NM, Tay FR, Hiraishi N. Effect of temperature on water sorption and solubility of dental adhesive resins. J Dent 2009;37:122-132.

5. Collares FM, Ogliari FA, Zanchi CH, Petzhold CL, Piva E, Samuel SM. Influence of 2-hydroxyethyl methacrylate concentration on polymer network of adhesive resin. J Adhes Dent 2011;13:125-129.

6. Takahashi M, Nakajima M, Hosaka K, Ikeda M, Foxton RM, Tagami J. Long-term evaluation of water sorption and ultimate tensile strength of HEMA-containing/-free one-step self-etch adhesives. J Dent 2011;39:506-512.

7. Malacarne J, Carvalho RM, de Goes MF, Svizero N, Pashley DH, Tay FR, et al.. Water sorption/solubility of dental adhesive resins. Dent Mater 2006;22:973-980.

8. Nishitani Y, Yoshiyama M, Hosaka K, Tagami J, Donnelly A, Carrilho $M$, et al.. Use of Hoy's solubility parameters to predict water sorption/ solubility of experimental primers and adhesives. Eur J Oral Sci 2007;115:81-86.

9. Nishiyama N, Tay FR, Fujita K, Pashley DH, Ikemura K, Hiraishi N, et al.. Hydrolysis of functional monomers in a single-bottle self-etching primer - Correlation of ${ }^{13} \mathrm{C}$ NMR and TEM findings. J Dent Res 2006;85:422-426.

10. Martin RB. Acid-catalyzed ester hydrolysis. J Am Chem Soc 1967;89:2501-2502.

11. Miletic V, Santini A, Trkulja I. Quantification of monomer elution and carbon-carbon double bonds in dental adhesive systems using HPLC and micro-Raman spectroscopy. J Dent 2009;37:177-184.

12. Reis $A F$, Giannini $M$, Pereira PN. Influence of water-storage time on the sorption and solubility behavior of current adhesives and primer/ adhesive mixtures. Oper Dent 2007;32:53-59.

13. Fabre HS, Fabre S, Cefaly DF, de Oliveira Carrilho MR, Garcia FC, Wang L. Water sorption and solubility of dentin bonding agents light-cured with different light sources. J Dent 2007;35:253-258.

14. Ito $S$, Hoshino $T$, lijima M, Tsukamoto $N$, Pashley DH, Saito T. Water sorption/solubility of self-etching dentin bonding agents. Dent Mater 2010;26:617-626.

15. Malacarne-Zanon J, Pashley DH, Agee KA, Foulger S, Alves MC, Breschi $\mathrm{L}$, et al.. Effects of ethanol addition on the water sorption/solubility and percent conversion of comonomers in model dental adhesives. Dent Mater 2009;25:1275-1284

16. Hosaka K, Tagami J, Nishitani Y, Yoshiyama M, Carrilho M, Tay FR, et al.. Effect of wet vs. dry testing on the mechanical properties of hydrophilic self-etching primer polymers. Eur J Oral Sci 2007;115:239245.

17. Hosaka $K$, Nakajima M, Takahashi M, Itoh S, Ikeda M, Tagami J, et al.. Relationship between mechanical properties of one-step self-etch adhesives and water sorption. Dent Mater 2010;26:360-367.

18. Ito $S$, Hashimoto $M$, Wadgaonkar B, Svizero N, Carvalho RM, Yiu C, et al.. Effects of resin hydrophilicity on water sorption and changes in modulus of elasticity. Biomaterials 2005;26:6449-6459.

19. Cohen $S$, Marcus $Y$, Migron $Y$, Dikstein S, Shafran A. Water sorption, binding and solubility of polyols. J Chem Soc, Faraday Trans 1993;89:3271-3275.

20. Hild G. Formation et propriétés élastiques de réticulats radicalaires préparés à partir d'esters méthacryliques. Makromol Chem 1976;177:1947-1972.

21. Kubo $S$, Yokota $H$, Yokota $H$, Hayashi Y. Two-year clinical evaluation of one-step self-etch systems in non-carious cervical lesions. J Dent 2009;37:149-155.

22. Beatty MW, Swartz ML, Moore BK, Phillips RW, Roberts TA. Effect of microfiller fraction and silane treatment on resin composite properties. J Biomed Mater Res 1998;40:12-23.

23. Ramrus DA, Berg JC. Characterization and adhesion testing of mixed silane-treated surfaces. J Adhes Sci Technol 2004;18:1395-1414.

24. Walter $R$, Swift EJ Jr, Nagaoka $H$, Chung $Y$, Bartholomew W, Braswell $\mathrm{KM}$, et al.. Two-year bond strengths of "all-in-one" adhesives to dentine. J Dent 2012;40:549-555.

25. Perdigao J, Dutra-Correa M, Saraceni CH, Ciaramicoli MT, Kiyan VH Queiroz CS. Randomized clinical trial of four adhesion strategies: 18-month results. Oper Dent 2012;37:3-11. 